\title{
ON DAVIS ON CONFINING, STRUCTURING, AND CHECKING ADMINISTRATIVE DISCRETION
}

\author{
VICTOR G. ROSENBLUM*
}

I

Davis and Discrettonary Justice

Although he subtitled Discretionary Justice a "preliminary" inquiry, Kenneth Culp Davis made a definitive addition to the literature and public understanding of the administrative process through his Edward Douglass White Lectures that engendered the volume. ${ }^{1}$

In reviewing Davis's Administrative Law Treatise ${ }^{2}$ a decade earlier, I had thought it a remarkable compilation and evaluation of court cases dealing with administrative agency practices and procedures, as well as the most comprehensive examination of the relationship to administrative law of such central legal concepts as stare decisis, res judicata, estoppel, official notice, ripeness, primary jurisdiction, and exhaustion of remedies. ${ }^{3}$ Although he recognized that many principles of administrative law, because of confusing or conflicting authorities, could not be asserted with certainty, Davis's objective as author of the Treatise was to make a systematic statement of principles derived from the huge mass of administrative law that had sprung up in recent decades. The data he examined were primarily Supreme Court decisions and lower court opinions that were based on agency rules, adjudications, and practices: related to them. Unsurprisingly, the evaluations he made consisted primarily of learned observations and incisive critiques of what the courts had said and done in response to what agencies had said and done.

My principal reservation about the Treatise was that it focused much more on formal law than on administration, more on the delineation of legal principles than on processes of decision-making. As a consequence, little was done to meet the concern of practitioners, administrators, and students about how administrative law develops and functions in reality. To the extent that Davis was then concerned with discretion at all, his emphasis was on judicial rather than on administrative discretion. Even in his examination of institutional decisions, Davis dealt mainly with the formal aspects of administrative problems. He discussed, for example, the extent to which deciding officers must personally consider evidence, the consultation of staff by examiners and agency heads, and the absences of or substitutions for officers and agency heads in decision sessions. ${ }^{4}$ Implicit in his analysis was the view that

\footnotetext{
* Director of the Program in Law and the Social Sciences and Professor of Law at Northwestern University; President, Law and Society Association.

${ }^{2} \mathrm{~K}$. Davis, Discretionary Justice: A Preliminary Inquiry (1969) [hereinafter cited as DiscreTHONARY JUSTTCE].

2 I-4 K. Davis, Administrative Law Treatise (I958) [hereinafter cited as Treatise].

${ }^{3}$ Rosenblum, Realities of Regulation, 20 PUB. Ad. REv. 219 (1960).

4 Treatise 36 -I29.
} 
the universe of administrative law was hierarchical, with the judiciary at its apex. He supported judicial discretion in applying rules such as exhaustion of administrative remedies because he believed the quest for "a neat word formula" that could eliminate discretion in determining when to grant judicial relief to be futile, if not undesirable. To channel the judiciary's discretion, he proposed consideration of such factors as the extent of injury a petitioner might suffer through delay, the degree of apparent clarity or doubt of administrative jurisdiction, and the significance of specialized administrative understanding. ${ }^{5}$

Discretion became a central, rather than a peripheral, concern to Davis during the Ig6o's, and Discretionary Justice was a major product of the broadening of his insights and inquiries. His objective shifted from a predominant effort to codify the law of the past and admonish judges about the law of the future to an emphasis on the primacy of discretion in administration at all levels. He sought "to dispel the virtually universal impression that discretionary justice is too elusive for study, ... to open' up problems that seem susceptible of further research and thinking, and ... to formulate a framework for further study." No longer preoccupied with the quest for judge-made principles of administrative law, Davis focused on the quality of justice in all facets of the administrative process and stressed that the strongest need and greatest promise for improving that quality for individuals "are in the areas where decisions necessarily depend more upon discretion than upon rules and principles and where formal hearings and judicial review are mostly irrelevant." "7

The key question he now posed was, how can we reduce injustice to individuals from the exercise of discretionary power? His framework for developing an answer was simple: unnecessary discretionary power should be cut back and the discretionary power that is found to be necessary should be properly confined, structured, and checked. Since this formulation constitutes an approach to an answer, rather than the answer itself, a critic would have to yield to cavil at this stage to denigrate Davis's contribution by attacking the vagaries of meaning of "necessary." One could draw on Justice Marshall in McCulloch v. Maryland to argue that necessary means convenient, or one could insist on confining the term to essentiality or indispensability to a goal or achievement. ${ }^{8}$ The point is that Davis did not stop with enunciation of the "necessary" and "properly confined" criteria. He rejected

\footnotetext{
3 Treatise $67-69$.

- Discretionary Justice vii.

${ }^{7}$ Id. at 216 (emphasis omitted).

${ }^{8}$ McCulloch v. Maryland, 17 U.S. (4 Wheat.) 316,413 (1819). In construing the meaning of "necessary" as used in the "necessary and proper" clause of the Constitution, Marshall observed that ". $[t]$ he word 'necessary,' is considered as controlling the whole sentence, and as limiting the right to pass laws for the execution of the granted powers, to such as are indispensable, and without which the power would be nugatory .... Is it true, that this is the sense in which the word 'necessary' is always used? Does it always import an absolute physical necessity, so strong, that one thing, to which another may be termed necessary, cannot exist without that other? We think it does not. If reference be had to its use, in the common affairs of the world, or in approved authors, we find that it frequently imports no more than that one thing is convenient, or useful, or essential to another."
} 
as a false hope the sharper delineation of statutory standards and pointed out the incongruity of the non-delegation doctrine in light of the reality of the commonplace power of selective enforcement. Instead, he espoused administrative rulemaking as the key to proper confinement and control of discretion. He insisted that "agencies through rule-making can often move from vague or absent statutory standards to reasonably definite standards, and then; as experience and understanding develop, to guiding principles, and finally, when the subject matter permits, to precise and detailed rules."

Concomitantly with his proposal for enlarged rule-making, he urged openness as a means for structuring discretionary power. He saw openness as a natural enemy of arbitrariness and called for open plans, open policy statements, and open findings and reasons in situations warranting informal discretionary action as well as in more formal realms of decision-making. ${ }^{10}$ With regard to the bearing of appeals on checking discretion, he noted that the natural system of administrative appeals from subordinates to superiors is less desirable than appeals to independent officers. An independent ombudsman could be a more effective critic of administration than a superior officer or a legislator. Davis was especially concerned about reducing powers of lenience and privilege since "the inescapable reality" is that the discretion of public officers to confer privileges or to be lenient, is power susceptible to abuses including the most egregious forms of discrimination, favoritism and caprice. ${ }^{11}$

The Davis of the White Lectures was more sensitive to and perceptive of realities of regulation than the Davis of the. Treatise. It would have been unthinkable for the author of the Treatise to conclude, as Davis does in Discretionary Justice, that "our jurisprudence of statutes and of judge-made law is overdeveloped; our jurisprudence of administrative justice, of police justice, of prosecutor justice-of discretionary justice-is underdeveloped. We need a new jurisprudence that will encompass all of justice, not just the easy half of it."12

Without claiming that all that has been done in administrative law and process research since the publication of Discretionary Justice is rooted in Davis, one can still justifiably credit him with commencing, inspiring, and spurring significant new probes of the nuances of administrative discretion that would otherwise have been neglected or discarded. Several prototypes of projects that are at least compatible with Davis's observations and admonitions are worth considering. Lest the reader conclude that my response to the "Discretionary" Davis is Ioo per cent encomium, it should be added that I am not yet persuaded that too little discretion is not as often to blame for denials of justice as too much discretion. In developing projects and in planning and allocating funds for research, I think it essential that we devote equal amounts of intellectual energy and tangible resources to probing positive

\footnotetext{
' Discremonary Justice 2 ig.

${ }^{10} \mathrm{Id}$. at 99-116.

${ }^{21} I d$. at $170-76,231-32$.

${ }^{19}$ Id. at 233 (author's emphasis).
} 
relationships between discretion and justice as we do to their dysfunctional interactions.

\section{II}

\section{Prototypes of Projects on Police Discretion}

Davis observed that the police constitute one of the most important policy making agencies of our society since "they make far more discretionary determinations in individual cases than any other class of administrators."13 $\mathrm{He}$ also found the amount of police activity measured in man hours to be more than forty times as great as the amount of governmental activity through all seven of the major independent regulatory agencies. Although he was not the discoverer of the discretionary dimensions of police work, Davis's work has shown the suitability and feasibility of intensive research on policies, procedures, and programs of the police. ${ }^{14} \mathrm{~A}$ current project at Northwestern University and an emergent one at Arizona State University help to illustrate the potentialities, if not yet the benefits, of implementing Davis's proposals.

In an attempt to discern' patterns in the conduct of police toward civilians in Chicago, the Law Enforcement Study Group, a joint research project of the Center for Urban Affairs at Northwestern University and a dozen other Chicago area organizations, undertook to examine policies and practices governing the use of fatal force by police officers. Little data of record was available prior to this study. Even when complaints were solicited or registered the information was usually considered too sensitive and controversial for public examination. A basic objective of the study was to determine the adequacy of institutions and mechanisms for reviewing incidents involving fatal force.

Through the Police Weapons Center of the International Association of Chiefs of Police, comparative statistical information on killings of and by police was collected on each of the five largest U.S. cities according to the r970 census. The death rate of civilians from police actions per ro0,000 population was found to be highest in Chicago- 0.95 from July I970 to March I97I as compared to 0.27 in New York, 0.28 in Los Angeles, 0.26 in Detroit, and 0.67 in Philadelphia. ${ }^{15}$ Chicago also scored highest on the civilian death rate per rooo police officers-2.53 compared with 0.66 in New York, 1.18 in Los Angeles, 0.77 in Detroit, and 1.67 in Philadelphia. ${ }^{10}$ With

\footnotetext{
${ }^{13}$ Id. at 222-23, $8 \mathrm{r}$.

${ }^{14}$ An excellent selected bibliography of both early and recent research into police roles, functions and discretion is found in American Bar Association Project on Standards for Criminal Justice, THE Urban Police Funcrion 296-303 (1972) (tentative draft). This comprehensive report draws heavily on Davis in developing and supporting its recommendations that "[p]olice discretion can best be structured and controlled through the process of administrative rule-making by police agencies. Police administrators should, therefore, give the highest priority to the formulation of administrative rules governing the exercise of discretion, particularly in the areas of selective enforcement, investigative techniques and enforcement methods." Id. at I25-I33.

${ }^{25}$ Law Enforcement Study Group, The Police and Their Use of Fatal Force in Chicago, 6 (1972).

${ }^{10} \mathrm{ld}$. at $\mathrm{Io}$.
} 
regard to police fatalities during the same period, Chicago was the highest with 7 and second highest in ratio of police deaths to department size.

Although the researchers could obtain statistical summaries and other aggregate data from the International Association of Chiefs of Police, individual departments, including the Chicago Police Department, were reluctant to make available their data on individual cases involving civilian deaths. As a consequence, one of the investigative research techniques employed was to identify incidents of civilian deaths at the hands of police reported in Chicago newspaper files. This information was then used to locate transcripts of inquests at the Cook County Coroner's office. Selected characteristics of the civilians who died were recorded by race, age, and sex; the locations of the fatal incidents were plotted on a map of Chicago; and whatever information was available on the characteristics of the policemen involved was analyzed. $70.9 \%$ of the civilians who died were black males, $3.9 \%$ were black females, $24 \%$ were white males and $x .3 \%$ were unidentified. ${ }^{17}$ The death rate by race per roo,000 population was found to be 5.35 for blacks and 0.86 for whites. The authors noted that during 1969 and 1970 , a black person in Chicago was more than six times as likely to die at the hands of police than a white person. ${ }^{18}$ Comparing the death rate with arrests, they found that blacks had a 2.01 death rate per I0,000 arrests of blacks, whereas whites had a 1.00 rate per I0,000 arrests of whites. ${ }^{19}$

The researchers next analyzed the stan'dards governing police use of fatal force and the structures and mechanisms for review of such force. Statutory standards of the state criminal law and administrative standards of the police department both govern review. The administrative standards showed that officers are specifically prohibited from firing into crowds; firing over the heads of crowds, except on specific order of a member of the Department above the rank of Captain; firing at a fleeing car, except one in which a person who has attempted or committed a forcible felony is riding; firing warning shots in the case of individuals where the use of deadly force is not permitted; and firing into a building or through doors when the person fired at is not clearly visible. ${ }^{20}$ In addition', an official Chicago police training bulletin cautions the officer to use "every possible means at his disposal" to avoid a killing and reminds him of the possibility of prosecution for voluntary manslaughter. ${ }^{21}$

Several different public bodies, including the internal division of the police department, the Cook County coroner, and the State's Attorney, were found to have authority and formal responsibility in review of cases of civilian death. Of 76 cases examined that involved fatal police force, the police pressed charges in two, the state's attorney presented charges to a grand jury in four, and a grand jury indicted a policeman and a trial was conducted in one. The coroner's office exonerated

\footnotetext{
${ }^{17}$ Id. at 19 .

${ }^{18} \mathrm{Id}$. at 20 .

${ }^{10} \mathrm{Id}$. at $2 \mathrm{r}$.

20 Id. at $30-32$.

${ }^{21}$ Id. at 32 .
} 
the police in all but two of the 76 cases, the same two in which the police department pressed charges. The authors of the report found that in 28 of the cases the evidence showed violations of administrative guidelines during the fatal incident. Ten of the 28 indicated substantial likelihood of criminal misconduct by the police. ${ }^{22}$ No administrative discipline measures were found to have been taken in any of these 28 cases. The researchers concluded that the public cannot be assured of the integrity of the police review process. As a result of the wide disparity between cases warranting official action and those in which action actually was taken, the authors called for a re-examination of the review system to determine whether and how structural defects contribute to the inadequacy of the examination of police use of fatal force. ${ }^{23}$ Two defects in the system of reviewing police use of fatal force-both of them consistent with Davis's critique-were cited for combining to compromise the integrity of the review process: "The agencies in the system have a close working relationship, an arrangement which precludes independent examination within the system; the review proceedings are conducted almost entirely out of view of the public, an arrangement which precludes independent examination from without."24

The Chicago report was obviously controversial and could be transformed wholly into political fodder in an election year. Needless to say, performance of such a project by the faculty and students of a university requires exceptional stress on objectivity, depth, and fairness. At the same time, the capacity of a university to accept leadership in research that has immediate public policy implications has added significantly to the checks and balances over arbitrary uses of discretion.

A more direct implementation of Davis's urgings about research into police discretion may be found in the Center recently established at Arizona State University Law School for study and research into police administrative law. Directed by Professor Gerald Caplan, previously general counsel of the District of Columbia Police Department, the first project of the Center will be a study of rule-making in law enforcement agencies. Davis's observation that "no other agency, so far as I know, does so little supervising of vital policy determinations which directly involve justice or injustice to individuals" ${ }^{\text {"25 }}$ was invoked as a demonstration of the need for the new Center, along with the exhortation of the President's Commission on Law Enforcement and Administration of Justice to police to develop and articulate concrete policies. ${ }^{26}$ The objective of the Center is not simply to survey and report on police policies and practices. Its active goal will be "to transform law enforcement agencies from comparatively passive and lethargic bodies, ever responding to

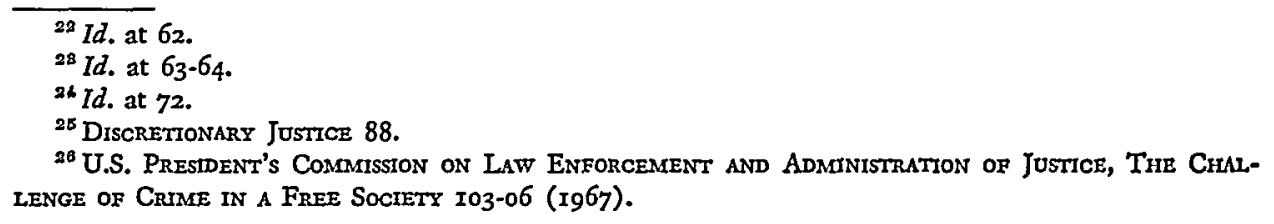


the cues or dictates of others, most notably the judiciary, into active initiators of policies reflective of their own goals."27

Discussions Caplan has had with police chiefs, legal advisors, and other police officials have re-enforced Davis's contentions and shown a need for comprehensive updating of existing police manuals. For example, one police chief told Caplan that community concern over a recent shooting might have been alleviated had the department had written statements of its rules and policies to present to the city council and other concerned groups.

The Center will endeavor to fashion model administrative orders for law enforcement agencies in such specific areas as service of arrest and search warrants, problems associated with stop and frisk and field interrogation, finger-printing policies, the settlement of minor disputes among neighbors and within the family, development of a citation and summons system, problems associated with vagrancy and disorderly conduct statutes, and policies relating to freedom of assembly and grievance procedures. The Center hopes to involve in its efforts groups often critical of the police, such as the American Civil Liberties Union, Urban Coalition, legal services organizations and anti-poverty organizations. Interest in' participation in the work of the Center has been manifested by a number of major city police departments including Kansas City, Phoenix, Dallas, San Antonio, San Diego, Oakland, New York, and Washington, D.C. Students at the Arizona State Law School will assist in the research along with the director, deputy director, junior attorney and participating consultants.

As prototypes of university involvement in appraising and assisting community needs, the Law Enforcement Study Group and the Center for Police Administrative Law are not expected to produce panaceas for the problems of police discretion. They can, however, help to institutionalize, channel and direct discretion toward constructive ends by giving visibility to basic information otherwise submerged or secreted and by developing proposals that can be weighed in politically neutral settings.

\section{III}

\section{Research About Potential Participants in Ombudsmen's Roles}

Like the university researcher, the ombudsman is usually outside the system he examines and his only real power is that which prestige and public opinion may accord him. A recent proposal to experiment with ombudsman-like roles for social workers and a report on performance of such roles by state lieutenant governors suggest the feasibility of additional checks on administrative discretion, implementing Davis's proposals, from inside operative administrative systems.

\footnotetext{
${ }^{37}$ Caplan, Rulemaking in Law Enforcement Agencies: A Proposal for a Police Administrative Law Center 1-2 (I972) (mimeo). Professor Caplan has expanded the proposal for the Center into a law review article, The Case for Rulemaking by Law Enforcement Agencies, 36 LAW \& CoNTEMr. PROB. 500 (x97x).
} 
A professor of social work at the University of Texas, for example, has considered the potential effectiveness of social workers as ombudsmen in the areas of mental retardation, crime, delinquency, housing, and welfare administration. ${ }^{28}$ While cognizant of Cloward's conclusion that there is no public commitment to justice, equity, or dignity in the social welfare system, Professor Payne insists that there are many opportunities for an ombudsman to help welfare department staffs improve at least the administrative fairness of their programs even if they can't eliminate public antipathy toward the poor. ${ }^{29}$ Payne does not feel that the social worker's position as an advocate of client interests in some instances would jeopardize the objectivity deemed a hallmark of the ombudsman, for he believes that any ombudsman must take on some dimensions of an advocate whenever he finds a citizen's complaint is justified and seeks to have the government reotify the error. ${ }^{30}$ Payne is especially enthusiastic about the capacity of social workers to perform as ombudsmen through impartial arbitration or neutral mediation in disputes between client groups and public agencies. The social worker's opportunity and task in such situations would be "to promote the public consensus that people-serving institutions should in fact serve people and to facilitate the implementation of such service."31 To protect impartiality and objectivity, Payne recommends that the social workerombudsman be designated an employee of a public legislative body or a private council of social agencies with funding authority, such as the United Fund, rather than an employee of any of the agencies in whose disputes he will be called upon to intervene. The relevance of law and public policy to ombudsmanship leads Payne to propose curricular changes in social work education that would emphasize legal doctrines and practices and also enable would-be ombudsmen to understand bureaucratic structure and organization beyond what is taught in the traditional social work administration courses. Whether ombudsman's roles can be effectively performed by social workers is conjectural of course. The obvious problem with Payne's proposal is that public legislative bodies and private councils of agencies have no guaranteed immunity against becoming partisans in conflict themselves. As Payne suggests, however, the feasibility of social worker-ombudsmen could well be the subject of active experimentation that could help, at the same time as it tested the new role, to enhance social work's professional purpose and philosophy. ${ }^{\mathbf{2}}$

In his study of lieutenant governors as political ombudsmen, Alan Wyner noted at the outset that lieutenant governors differ from the traditional model of the

\footnotetext{
${ }^{28}$ Payne, Ombudsman Roles for Social Workers, I7 Socrat Work, January, x972, 94. Earlier discussions of potentialities of social workers as ombudsmen were contained in Cloward, An Ombutsman for Whom?, I2 Socras WoRk, April, 1967, at II7; Zweig, The Social Worker as Legislative Ombudsman, I4 Soctal Work, January, 1969, at 25; and Payne, An Ombudsman for the Retarded?, 8 MENTAL Retaron: TION, October, 1970, at 45.

${ }^{20}$ Cloward, supra note 29. See also Cloward \& Elman, Poverty, Injustice and the Welfare State, 202 THE NATION 230 (1966).

${ }^{80}$ Payne, Ombudsman Roles for Social Workers, stura note 28, at 98.

81 Id. at 99 .

${ }^{32}$ Id. at xoo.
} 
ombudsman in two major ways. ${ }^{33}$ Whereas traditional ombudsmen cannot hold another public office during their terms and are rarely interested in future political office, lieutenant governors are elected politicians with major responsibilities as well as continuing political aspirations. Furthermore, whereas ombudsmen traditionally owe their ultimate allegiance to the legislature, lieutenant governors are generally executive officers with at least as much identification with the executive branch as with the legislature. For lieutenant governors, "opportunities for conflict of interest abound." ${ }^{\text {34 }}$ Perhaps surprisingly, Wyner found that, in strictly quantitative terms at least, such conflicts have not arisen in' the vast majority of instances thus far. ${ }^{35}$

Focusing on the ombudsman experiences of Lieutenant Governors Mark Hogan of Colorado, Paul Simon of Illinois, and Roberto Mondragon of New Mexico, Wyner's study showed that the office of ombudsman had no indigenous attributes that ordained it with any natural affinity for lieutenant governors. Each of the state officials voluntarily and independently sought out the responsibility and established his role as ombudsman-Simon and Mondragon in their platforms for office and Hogan in the course of his inaugural speech. In Wyner's appraisal, "a combination of personal political ambition, plus a genuine interest in resolving people's grievances against administrative agencies provided the motivation for Hogan, Simon and Mondragon to adopt political ombudsman roles." ${ }^{36}$ The public seemed to welcome a new avenue of possible redress.

Welfare, employment, and licensing cases led in all three states for ombudsman attention-the typical welfare complaint alleging wrongful diminution or inadequacy of benefits, the typical employment case alleging unfair personnel practices by the state or a need and desire for a job, and the typical licensing case alleging excessive delays or mistakes in handling automobile registration certificates and drivers' licenses. The most common causes underlying complaints were delays because of excessive paperwork, buck-passing, and inadequate understanding by citizens of the law. ${ }^{37}$

Office efficiency was not a hallmark of the lieutenant governors' ombudsman roles. Procedures for complaint handling were developed ad hoc, staffing was sparse, and formal records almost nonexistent. Yet office inefficiencies did not lead to operational ineffectiveness. Thousands of citizens did receive hearings, and significant reductions of friction between agencies and the public were achieved. Moreover, the political ombudsmen were not politically embarrassed when they found that up to fifty per cent of the submitted complaints were unjustified. They reported that they received as many expressions of appreciation from initiators of complaints found after investigation to be unjustified as from those whose complaints were found justified

\footnotetext{
${ }^{83}$ Wyner, Lieutenant Governors as Political Ombudsmen, 12 Bulletin of the Institute of Governmental Studies of the University of California, No. 6 (I97I).

${ }^{34}$ Id. at 2.

${ }^{85}$ Id.

${ }^{80}$ Id.

${ }^{37}$ Id. at 3.
} 
and were remedied..$^{38}$ One of the reasons for the high reported level of efficacy of the lieutenant governors as ombudsmen stemmed from the routine, non-sensational nature of the cases brought to their attention. The substance of the problems had no major ramifications for political survival or advancement.

Wyner concluded that traditional ombudsmen probably enjoy greater public credibility than the lieutenant governors since many citizens view the lieutenant governor-ombudsman as a public relations gimmick to win votes. Nonetheless, "it remains to be seen" whether traditional ombudsmen are more effective in the American polity. In any event, Wyner found the political ombudsman's role viable as long as he does not seek to perform his tasks for political advantage, has an adequate staff, has at least tacit support from the chief executive, and has the cooperation of agency personnel. ${ }^{39}$

IV

Too Much v. Too Littue Discretion

Consistent with Payne's stress on mediational aspects of the proposed social workerombudsman role, Wyner found that relatively few cases pit the lieutenant governorombudsman against agencies in an adversary position. Simply hearing the two sides often allowed the lieutenant governor "to clear the air by informing both parties of his findings." ${ }^{\text {0 }}$ If a dominant need in effectuating redress for citizens is for heightened mediational roles and if the great majority of complaints submitted to the lieutenant governors concerned paperwork, buck-passing and inadequate understanding of the law, it should be apparent that, without detracting from the importance of Davis's emphasis on confining discretion, we need to go beyond seeking better checks an'd controls. We need equally to determine ways to stimulate imaginativeness, creativity and efficiency in the performance of administrative functions and the delivery of services.

A research project to be undertaken by Professor Larry Hill of the University of Oklahoma will help us to learn, with regard to the federal agencies at least, how much of the problem of administrative discretion is arbitrariness through too much discretion and how much of the problem is indecision and buck-passing because of: too little discretion. ${ }^{41}$ In his project prospectus Hill notes the evidence of growing public distrust of bureaucracy and comments that, although some citizens complain about their treatment by administrative agencies, we still don't know enough about the nature and subject of the complaints or about the processes and devices for their resolution. In a comprehensive examination of what he terms "the consumptioncomplaints subsystem" of the American political system, Hill will identify com-

\footnotetext{
${ }^{88}$ Id. at 5 .

${ }^{30}$ Id. at 5,6 .

${ }^{30} I d$. at 4 .

"1 Hill, Relationships Between the Rulers and the Ruled: The Consumption of Government and the Processing of Federal Complaints (mimeo) (1972).
} 
plainants and their complaints through analysis of the files of major agencies. ${ }^{42}$ Through interviews with samples of that population', as well as a random sample of others who may or may not have been complainants, he will seek to measure and interpret attitudes toward governmental agencies and to correlate experiences and attitudes of his informants with their pertinent sociological, psychological, and economic attributes.

Hill will also endeavor to evaluate relationships between ranges of agency discretion and their procedures and practices in responding to complaints. ${ }^{43}$ Building on Discretionary Justice as well as on Gellhorn's When Americans Complain, he will be able to speak authoritatively about which Americans complain about what to whom and with what consequences in their relationships with the federal bureaucracy. ${ }^{44}$ Of course, this assumes wholehearted cooperation by the agencies with Hill, a state of affairs not invariably borne out by experience-as researchers from Indiana University and the University of Illinois had occasion to learn recently.

Professors Julius Getman and Stephen Goldberg had to take their case to court before the high degree of cooperation they thought had been assured by the National Labor Relations Board reached that level in fact. Getman and Goldberg, both former NLRB attorneys, had a grant from the National Science Foundation to study voting in elections ordered by the NLRB. Proposing to question willing employees about their attitudes toward the bargaining-agent election process and especially about the impact on their votes of campaign tactics utilized by employers and unions, the professors asked the agency for the names and home addresses of employees eligible to vote in the elections they were studying. The Board had established a structure of rules governing the behavior of parties during a campaign, and the specific purpose of the Getman-Goldberg study was to provide an empirical foundation for evaluating these regulations. ${ }^{45}$ In April, I970, the Board denied them the voter lists on the ground that their study could upset the "laboratory conditions" necessary for conducting a fair election. In August, after negotiations for the lists proved unfruitful, the professors filed suit in the District Court, claiming that they were entitled to the lists under the Freedom of Information Act. ${ }^{46}$ In January, 197x, the District Court ruled that the NLRB had failed to establish that it had the authority or discretion to withhold the requested information, a judgment that was stayed pending appeal. ${ }^{47}$ On August 3r, I97r, the Court of Appeals for the District of Columbia Circuit upheld the professors' position and commented that 'the Board's position suffers from the obvious self-justifying tendency of an institution which in over $3^{0}$ years has itself never engaged in the kind of much needed systematic empirical

\footnotetext{
Id. at 4 .

${ }^{13} I d$. at $4-7$.

"W. Gellhorn, When Americans Complain: Governmental Grievance Procedures (ig66).

${ }^{40}$ Getman v. NLRB, 450 F.2d 670,67I-72 (D.C. Cir. I97I).

15 U.S.C. $\$ 552$ (1970).

17 Judge J. Skelly Wright reviewed the history of the case in the course of his Court of Appeals opinion in Getman v. NLRB, $45^{\circ}$ F.2d 670,671-72 (D.C. Cir. I97I).
} 
effort to determine the dynamics of an election campaign or the type of conduct which actually has a coercive impact." 48

The experience of Getman and Goldberg, even with the delay of almost a year and a half occasioned by the agency's intransigence and the time required for judicial review, shows that redress through the adversary system may still, on occasion, be the most effective means for coping with agency arbitrariness. Regardless of the ultimate contribution of the Getman-Goldberg voting study, countless academic researchers, including Professor Hill, may have occasion to be grateful to the two law professors for establishing so stunningly the right to agency information in the conduct of research.

Side by side with the glow of satisfaction left by the Court of Appeals ruling in the Getman case, there is a malaise engendered by one aspect of the case. The facts suggest that formulation of rules-which the NLRB had prescribed in abundant detail for the conduct of elections-may freeze requirements into a time-worn and dysfunctional mold that stifles innovation and change and evokes blatant arbitrariness in its defense. In channeling and controlling discretion, rule-making must not prevent or discourage reappraisals and revisions of rules. On the contrary, there ought to be built-in provisions in rule-making proceedings for testing and evaluating the functions and consequences of rules at regular intervals. Otherwise, the danger is that the rules may vest, rust, and atrophy, but still be followed rigorously for perhaps no other reason than that often cited by mountain climbers to explain their urges to ascend, "because they're there." How to update and en'ergize administrative practices, how to transcend the administrative syndrome of "I don't make the rules, buddy, I just have to follow them" when the rules have become outmoded, and how to achieve interactions between the public and administrators that deliver justice in individual cases through allocation and chann'eling of discretion are at least as worthy of attention as how to keep administrators from exercising discretion in whimsical, arbitrary, and unjust ways.

In his discussion in the Treatise of interpretations of the rule that no one is entitled to judicial relief until the prescribed administrative remedy has been exhausted, Davis pointed out that the Supreme Court's holdings were often irreconcilable and that "the word formulations in the opinions are inadequate, conflicting and usually affirmatively misleading." ${ }^{.49}$ He preferred the frank statement by the Court of Claims in Adler v.US. ${ }^{50}$ to the "Supreme Court's absolutes in either one direction or the other." ${ }^{\text {"1 } 1}$ The Court of Claims had asserted that there is nb absolute requirement that a party exhaust his administrative remedies before coming into court. "The court may entertain his suit before he has done so, if in its discretion it thinks the circumstances make it appropriate to do so." Just as a "neat word formula"

\footnotetext{
${ }^{18}$ Id. at 675 .

43 Treatise 67 .

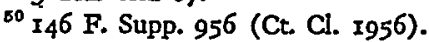

82 Treatise $69 \mathrm{n} .9$.

${ }^{2}$ I46 F. Supp. 956, 957 (Ct. Cl. I956).
} 
for exercising such judicial discretion probably is not feasible, ${ }^{53}$ there are equal limits and drawbacks to precise formulae for checking administrative discretion. Davis, of course, recognizes this fact in Discretionary Justice when he rejects "the extravagant version of the rule of law" that declares that legal rights may be finally determined only by regularly constituted courts and reminds us that "eliminating discretionary power would paralyze governmental processes and would stifle individualized justice." Ni Nonetheless, his stress in striving to reduce injustice to individuals is on cutting back, confining, and checking discretionary power. He does not delineate a framework for coping with categories of cases in which injustice stems from paucity of discretion.

Davis's use of "structure" may provide a solution to this seeming overemphasis on restricting discretion. Although he generally sandwiches references to structuring discretionary power between calls for confining and checking it, thereby fostering the impression that it is another limitation, Davis's proposed instruments for structuring discretion could actually help to invoke and apply it in appropriate cases where it currently lies dormant. He notes that "structuring discretionary power is different from confining it, although the two may overlap"; and his call for open plans, open policy statements, open rules, open findings and reasons, and open precedents can protect against arbitrariness from failure to exercise discretion as well as against arbitrariness from its use. ${ }^{55}$ Proper structuring of discretion, like the constitutional principle of checks and balances, could pluralize planning and initiative while at the same time facilitating controls over the boundaries of power.

\section{CONCLUSTON}

In Discretionary Justice, Kenneth Culp Davis added a new dimension to his already monumental contribution to the formulation, analysis, and critique of legal facets of the administrative process. His probe and presentation of a framework for future research into the nuances of discretion, a topic that did not qualify for listing in the index to his Treatise a decade earlier, have been instrumental in setting agendas for policy makers, scholars, and practitioners that will enhance the capacity of the administrative process to be both just and fair. In the course of this article, we have examined prototypes of projects and proposals toward these ends, such as the Law Enforcement Study Group at Northwestern University, the Center for Police Administration at Arizona State, Payne's observations about social workers and Wyner's study of lieutenant governors as ombudsmen, Hill's design for determining the nature and consequences of citizen complaints, and Getman's and Goldberg's tests both of the validity of the NLRB's rules for elections and of the NLRB's discretion to withhold information from researchers. Works such as these will assist in resolving the massive problems of administrative regulation today.

\footnotetext{
3 Tresttse 69.

- Discretionary Justice 28-44, 217.

${ }^{85} I d$. at 97 .
} 
Marver Bernstein recently decried the fact that "after nearly a century of regulatory experience in an industrial economy, we are unable to identify, on the basis of rigorous analysis rather than impressionistic judgments, the requisites of acceptable administrative performance." ${ }^{20} \mathrm{He}$ urged that the talent and energy devoted to protecting the regulated from unfair procedures and to minimizing effects adverse to regulated clienteles now be targeted on the problem of "designing and improving systems of regulation that have a fighting chance of achieving some useful public result." ${ }^{357}$ Perhaps Professor Davis, having completed in Discretionary Justice the journey to the second dimension of his professional role, just might be prepared to lead the rest of us into administrative law's Consciousness III.

${ }^{50}$ Bernstein, Independent Regulatory Agencies: A Perspective on Their Reform, 400 Annals I4, 26 (1972).

${ }^{67}$ Id. 